Journal of Social and Development Sciences (ISSN 2221-1152)

Vol. 6, No. 4, pp. 92-97, December 2015

\title{
Sustainability Farmers Rice Farming of Rural Communities in the Spiritual Meaning Perspective of Seed Storage
}

\author{
Irmayani*, Darmawan Salman, Amaluddin, Sitti Rahbiah Busaeri \\ Hasanuddin University, Makassar, Indonesia \\ *irmaumpar@yahoo.co.id
}

\begin{abstract}
This research aims to reveal in the spiritual of meaning contained in the farming of rice seed storage of rural communities in the village at Bone-Bone. This research uses a qualitative approach in the phenomenology of perspective and will be interpreted in the definiton of the symbolic interactionism. The result of this research indicates that the stages of the storage that begins with the way collect it in the form of malai rice that has been drained in a small house with called landak. Storage at a its own will be do it because the farmer glamorize the seed of rise with no treat in vain. The seed pf rice who are stored in a place that exalted so that would prevent anyone to overstep and and even stepped deliberately because it was considered not appreciate the seed of the rice which is the source of life. This action effect has meaning that for all beings actually have a close relationship with human life itself, treated well even of plants will be upheld especially if the relationship among humans and other animals is required ethics are maintained so constantly continue in the future, involving the meaning of an action to keep the sustainability of rice farming.
\end{abstract}

Keywords: Sustainability, rice farm, rural communities, meaning of spiritual, seeds storage

\section{Introduction}

Ecological crisis that occurred at this time sourced in errors of philosophical fundamental in the understanding or the human perspective of him, nature, and human life, especially of interacting with nature. Production activity and consumer behavior will be give birth attitude and exploitative behavior. Besides that understand about materialism, capitalism, and pragmatism with the vehicle of science and technology has come to accelerate and aggravate of ecological damage in system social. According to Linn White Jr. 1967 say that sources of environmental crisis environmental crisis of human resources this time it's most influenced by beliefs about the nature. We are and destiny, is by religion, so that recommend from white, Jr, 1967 to get tradision of eastern religions in build cosmology which spiritual minded. The achievment crisis is reflection of spiritual crisis it most essential in human life, nature has been denigrated and abused on human rights for the needs of human life and create exploitation without end, Hossein considers that spiritual understanding of Islam sees nature as a figure of "life" that has the right to exist, worthy of respect and getting protection and maintenance (Hossein, 1995). This maintenance and protection which become the embodiment of human's role as caliph on earth. The nature of reality is not created by accident as the view of some western scientists, but with the right plan. Therefore, according to Islamic Spirituality looking nature has real existence, objective, and work in accordance with applicable law remain (qodar), is not the same as the view of rationality which states that the nature is artificial and virtual (illusion).

In line with the growing awareness of their thinking as natural to think makes they of embrace spirituality and respect the role of religion in social life gave birth to humans who are good grateful and not greedy manage their resources. According to David E Cooper dan Joy A. Palmer (Spirit of The Environment, 1998) the compile of write from variety of international scholar from various fields such as philosophy, religion, science, education, literature, antropology which agree that is spiritually minded of nature is to be real needs in our effort and save planet earth. Critical opinion by Lynn Townsend White, Jr in her thesis with title is The Historical Roots of Our Ecologic Crisis, published in journal science Vol. 155 (Number 3767), (1967), has explain that science and modern technology which has caused of various patology social and ecology crisis, actually, this is rooted from the jewish-christian of tradition. It is baded on the story ' creation'. Reads "Be fruitful and multiply; fill the earth and conquered it, and have dominion over the fish of the sea and the birds of the air and over every living thing that moves on the earth. according to white, say that 'subdue' and 'have 
dominion' became a central doctrine that encourages exploitative attitude of man over nature. For White, the doctrine is paradigmatic thought to trigger the birth of dualistic break the existential relationship of God and nature and the human and nature. He shows that the mentality of the Industrial Revolution, which is considers only the earth resources for human consumption, it is actually much older than actuality of the engine so as to allow humans to destroy and exploit its natural of are heavily. Therefore, the Christian religion must be responsible for any environmental damage caused by the application of science and technology modern, so White suggested to embrace pantheism or religious traditions East (Islamic Spirituality) in building spiritual cosmology.

Hossein found that presenting god in every aspect activity of human is defined as the concept of thinking and acting that is associated with "the unseen" that create and organize of the human and nature. So God, human, and the third has a unitary nature and function relationship status. The relationship is a loud call to wake from the dream ego dangers of science and humanity in conquering nature. These relationships can bring humanity on the right path towards harmony with nature.

\section{Literature Review}

Spirituality : While a few decades the term spirituality has become a common language to describe activity the search for transcendence which is conducted by someone or individual. Spirituality comes from English language which when translate the meaning is spiritual or soul that means everything is not physical, not worldly and not in ways that are materialistic. The opine that the spiritual have four theme, followed is; (1) as a source of value, the meaning and purpose of live beyond the self, including a sence of mistery and selftranscendence. (2) a way to understand and comprehend of life. (3) inner awareness and integrated personal (Nelson, 2009). Spirituality has integrative function and harmonization involving inner unity and connectedness with other human beings as well as the broader reality that gives strength and ability of the individual to become transcendent. In termsin terms of contemporary and scientific literature, spirituality has a number of common meanings and definitions. This difference reflects the fact that spirituality is a term which has a broad of meaning, there a few domain of meaning that may differ between cultural groups, nationalities and different religions. (Dale and Daniel, 2011) divide the concept of spirituality in three forms is, follow:

- The form in spirituality of oriented God,the meaning is consideration, the view and practical of the spirituality based of theology or rests on top of the revelation of God. It can be found in virtually all forms of the practice of institutionalized religions, such as Islam, Christianity, Judaism, Hinduism, Buddhism and others.

- The form Spirituality of oriented world/nature(world-oriented), the form of spirituality based on human harmony with ecology and nature. We've seen the secret, which many once mentioned about the natural harmony with the human mind, that nature is the magnetic field that will respond to the human mind, because that man is obliged to continuously develop positive thinking that the universe give feedback positive also headed life inwardly opportunities.

- The form Spiritualistic-humanistic, who based his spiritual form in optimizing the potential of goodness and human creativity at the peak of achievement included in this achievement.

A number of scholars sees spirituality and religion as different concepts. The meaning of spirituality is involves one's relationship with that something holy, sacred, large or grand, as distinct from religion which involves adherence to the beliefs and practices (rituals) certain, although he also acknowledged that both are sometimes difficult to separate and often cannot be distinguished in theory and the research. But seperating them between spirituality and religious have advantage, it can give recognition of various flow the spirituality outside tradition and who was the people social. The reality, spirituality it's true with a skeleton idea and the culture of the west people which focused of individual and of them experience than of needs and the experience community of a wider. This contains the meaning of that spirituality will given opportunity to any individual to have a spirituality individally than only follow of religious mayority that applies of a community the larger. remember that the character or typology of western society that tends individualistic than collectivistic. Nelson has found that religion and spirituality have an independent effect on the development of rapid, although spirituality also has an effect on religiosity. They find the spirituality that involves orientation to help other people and do a good job, and participate in activities based on personal interest 
(self-interest). This contrasts with religiosity, which involves matters related to faith and institutional influences. Definition of Spirituality According to Webster's dictionary the word "spirit" comes from the Latin noun "spirits" which means breath and the verb "spipare" which means to breathe. See the home he said, to live is to breathe, and have the means to have a breath of spirit (Hasan, 2006).

Spirituality is enlightenment in achieving the purpose and meaning of life. Spirituality is an essential part of overall health and well-being of a person. Mean of that spirituality is the foundation for the growth of selfesteem, values, morals and a sense of belonging, spirituality gives direction and meaning to life (Zohar and Marshall, 2005). Spirituality is the belief in the existence of non-physical strength that is greater than the strength of ourselves; a consciousness that connects us directly to God, or whatever we call as the source of our existence. The spirituality is not to be associated with the proximity of a person with an aspect of divinity, because according to a humanist or atheist can also have spirituality. In his book mentioned that formal religion is a set of rules and beliefs are imposed externally. He is a top-down, inherited from the pastors, prophets and holy books or implanted through family and tradition. Meanwhile spirituality is internal innate ability of the brain and the human soul, which is the deepest source of the core of the universe itself.

Spirituality in English version is spirituality, derived from the word spirit means spirit or soul. Spirituality is the impetus for all human action, then the new spirituality can be said to be the impetus for a response to the problems of contemporary society and the concrete. The new spirituality is different with a special form that is more in the form of formal teaching. In the context of Islam, in fact it can be said of the new spirituality is meant here is the life of faith itself, which in Islam is stated and derived from primary belief that "There is no God but Allah and Muhammad is the messenger of God". Recognition and testimony in the heart that does not happen incidentally but continuously throughout life and is therefore a demand for the implementation of a faith that is a call to do good and do despicable ban which also takes place continuously throughout life and eternal nature. When it manifests in the liver recognition activity, it will be humane and therefore impure, thus open to criticism and objections and on the contrary open to support from any direction. By itself the size of the demands of good and bad prohibitions are rational and follow universal humanitarian standards alone, while the confession and the testimony of faith gave a commitment basis.

Spirituality is a search for something meaningfull is a search for the sacret (Snyder and Lopez, 2005). Spirituality is an effort to discover what is meaningful to humans then maintain and keep. Individuals who find the root of the meaningfulness life will try to maintain their relationships with God and looking at every aspect of his life is based on relationships built with the Lord. Various virtues (virtues) and strength (strenghts) emerged through this relationship. Build a spiritual life can not be separated from building a relationship with something meaningful. Thus, for the sake of building a spiritual life, individuals can be performed in the ritual forms of worship which constitute the means to maintain individual connectedness with God as personally meaningful to the individual, so spirituality can be measured by measuring how successful individuals in the search for something meaningful by using criteria such as oriented spirituality as spiritual well-being. Management of natural resources by spirituality Spirituality management of natural resources closely related to the concept of the tragedy of the Commons proposed, a biology and ecology (Hardin, 1968). This concept describes the environmental collapse of the commons as a result of irresponsibility and selfishness of individuals or groups of people belong together because the fight over was so eventually an extinct or in crisis. Pollution of air, water, land, and oceans caused by waste disposal modern technologies that lead to environmental degradation and disasters such as the depletion of the ozone layer, melting of polar ice, water pollution and marine, floods, landslides, mud and others showed the phenomenon of tragedy of the Commons.

This happens because of the weakness of human spirituality and slumped in a spiritual crisis deeply marked in a crisis outlook on life, ethical behavior, and the theology of religion or wisdoms cultural traditions embraced people increasingly melted and led to greed for nature to be exploited to the utmost. Spiritual crisis characterized by the view desecration of nature. Nature is not considered as being of the values of divinity, so that people do not pay attention to the ethics or binding rules and limit its relationship with nature. Nature only as object of desire to meet their needs. Along with improving standards of living and awareness of the importance of health, most people need quality rice is beneficial for health. Brown rice is a source of carbohydrates, a source of staple food is beneficial to health and is known since $2800 \mathrm{BC}$. The rice, especially 
brown rice, as well as the main source of carbohydrates, also contains protein, beta carotene, antioxidants and iron. Fiber brown rice is relatively easily absorbed by the intestine than wheat, so as to ease the burden of the intestine in doing peristalsis (Indrasari and Adnyana, 2007) and the launch system of the digestive tract.

The brown rice is the leading commodity as a functional food for health. Fiber brown rice can be used to control blood sugar levels, making it the best choice for people with diabetes. Brown rice has anthocyanin pigments that act as antioxidants to prevent various diseases such as coronary heart disease, cancer, diabetes, and hypertension (Suardi, 2005). Sustainable agricultural systems in some of these commodities by maintaining local seeds that have been developed and environmentally friendly based management so that the color is retained (red). Similarly, access to markets and support the government in its management can be done by expanding the network of farmer groups gain access to information in the capital in order to maintain the supply chain is maintained. Increased food production should be done in ways that are sustainable not reduce and impair the fertility of the soil, do not increase erosion, and minimize the use of and dependence on natural resources that are not renewable, life-sustaining rural communities are equitable, increasing employment opportunities and providing community life worthy and prosperity, reduce poverty and malnutrition, does not endanger the health of people who work or live in agricultural land, and also the health of consumers of agricultural products are produced, improving environmental quality in agricultural land and rural areas and preserving natural resources and biodiversity, preserving local resources and knowledge of traditional societies as a rural community maintained their integrity.

\section{Methodology}

This type of research used in this research is descriptive, with a qualitative approach (qualitative research) which aims to understand the object under study in depth and not to make generalizations, but rather to make in-depth explanation of the meaning behind the object of study. The location study was conducted at the Bone-Bone, Enrekang, this village is an area of national level as a healthy village nationwide because of the success of its citizens to agree on the rules (Perdes) with the smoking ban anyone who lives in this village and the people immigrants who enter into this village. The informants were taken in this study is the individual households engaged in agricultural activity in the village of commodity rice is then pictured through phenomenology study that will be interpreted through spiritual meaning and interpretation of meaning through the lean concept meaning Symbolic Interactionism.

\section{Results and Discussion}

Rice farming practices: Rice grown in the village of Bone-Bone is a local rice which has been cultivated for generations. Since the beginning of villagers Bone-Bone has been growing rice using these local varieties. Rice took time for 6 months to be harvested to produce red rice (Oryza nivara sp). Rice brown rice is one kind of rice in Indonesia, which contains high nutrition. The results showed that red yeast rice extract solution containing protein, unsaturated fatty acids, beta-sterol, camsterol, stigmasterol, isoflavones, saponins, $\mathrm{Zn}$ and $\mathrm{Se}$, lovastrin, and mevinolin-HMG-CoA. The last element is a reductase inhibitor that can reduce cholesterol synthesis in the liver. According to the Ministry of Health is mashed brown rice contains $7.3 \%$ protein, $4.2 \%$ iron, and vitamin B1 $0.34 \%$. Brown rice porridge mixed with milk is baby food recipes aged 4 months to 1 year (Suardi, 2005). Based on the nutritional content of brown rice is very good for the area food insecurity status, especially people who are malnourished. Rice with a high protein content is very useful in improving people's nutrition. Besides consuming brown rice can prevent diseases such as cancer, cholesterol and coronary heart disease with comparatively very low cost. Commodities that this area is cultivated rice plants that produce brown rice cultivated with traditional farming systems. Making the landscape terraces with mountain areas fascinate the arrangement. Livestock farming systems using mutual cooperation in preparing the land and planting rice citizens assist in this group will be the distinctive characteristics of their togetherness in harmony.

Irrigation systems are managed and fair result was never a problem in the cultivation of red yeast rice. Side stretched natural scenery of rice fields surrounded by trees that grow fast and should not be felled, it is not surprising source of clean and cool water for irrigating crops cultivated almost available all year round. 
Society believes that forest ecosystems such as the growth of others who also have the same right to live with human beings so that its existence should be respected. Semi-organic farming systems that are environmentally friendly so dominating farmers in their economic behavior, utilizing natural pesticides and compost are produced resulting in rice rich in omega 3 has a high sales value and popular consumer. Seeds of red rice that will be used as planting material beforehand stored in small homes designed distinctive called Hedgehog, the seeds have been the best with expectations when planted later will produce good anyway, people's spirituality is believed that the seeds of the ovule rice should not be placed parallel to the ankles especially bypassed, seeds chosen it must be lifted in a safe place because rice is needed as a source of energy to continue life so that it appears also when they eat, then it should not be left one item because mubazzir, and spiritual Islam mubazzir it is an act of that should not be emulated.

Spiritual Meanings of Seed Storage: There are several procedures that must be met when providing seeds to be prepared as a planting material, namely: First is making rice seeds that are stored in a small house called hedgehog. When taking a rice seed in the person hedgehog should be in a state of pure, good men and women that anyone who will take the first seed purify themselves first. The second is a greeting upon entering the hedgehog to take seed as regards blessing and appreciation for life and those of other seeds that are in the hedgehog. The third is to prioritize the right side when entering and start making rice seed activity carefully and silently continued to mutter gratitude and some good hope for the efforts rice cultivation this season. Once the seeds have been prepared, and the left foot to bring out the seeds are then wrapped in a clean cloth and carried by means upheld (put the seeds wrapped over head). (Nene, 2012) explains that one's spirituality will be affirmed thought immaterial that are not captured by sensory and emphasizes that a person would be wise to manage their resources to manage both lust, greed becomes inevitable that the resource is not depleted and become extinct. Keeping natural resources as part of a life that benefits to be managed wisely and prudent not exploit and arbitrarily treat. This paper will refer to the perspective of spirituality in the meaningfulness of life, in which spirituality is not only limited to religious rituals practiced and limited appreciation of the ecology and the environment, but much more emphasize the meaning of life on the award on nature (meaning ecological, social, religious) aspects of life are nearby when people live and meaningful for someone else then that's true spiritual nature. Therefore this research, perspectives that are considered relevant to understanding spirituality relationship with the village communities living pattern Bone-Bone is a spiritual perspective will meaningfulness of life (the meaning of life) who gave birth to the individual who finds the roots of the meaningfulness of life by maintaining a relationship with his Lord (Nurtjahjanti, 2010).

All the Bone-Bone villagers has a horn as a storage area yields obtained mainly rice. Hedgehog as a grain storage are built to resemble traditional Minangkabau house without stairs (the stairs will be installed if going up the hedgehog house only). In the manufacture of hedgehog expected good rice seeds as planting materials and foodstuffs preserved and maintained in that condition. This hedgehog house has created a prism pole side 5 pieces, one of its functions so that the mice are not easily creep upwards. Besides, there is also the understanding of farmers that side of the pole are made into five is to remind them that our lives can not be separated from the five times it has always done every day, it is the five daily prayers were regarded as the pillar of religion should be enforced. But this time when farmers make their new hedgehog more use of tree trunk poles round. This tree grows easily in this village and have a population that much. According to the farmers of this tree has strong durability and long, not eaten by termites, and can not be skipped mice so that manufacture of new hedgehog in this village has been dominated by this tree as a pole urchin farmers. Besides, the availability of wood there has been more used to manufacture pole home-Bone Bone villagers. In addition to save the harvest, sometimes also when there are other crops, such as corn or red beans can also be stored in the hedgehog, but it will be dominated by the content of rice as the most in a hedgehog. When stored in the Hedgehog has always followed a lot of hopes of beautiful (in the liver) so that they are kept must be arranged neatly and in a clean condition and expected no wasted rice were scattered and fell in around hedgehog floor. Spiritual meanings in rice seed storage practices can be described that rice is a source energy of life deserves to be rewarded and exaltation in practice maintenance and storage. Store grain by putting it in a clean container and to avoid any disturbance is one way to exalt the rice itself. Rice grown from Markowitz panicles up Buir-grain is a life process in involves various elements and components of another life, consisting of relationships holistic between plants, nature, and humans are interlinked and shape emotional 
bond therein, so that the components of the with other components to support each other achieve their continuity, without sacrificing other components.

\section{Conclusion and Recommendations}

Making of spiritual practice rice farming as a way to exalt the presence of rice that would be a source of life energy and heralded as a form of gratitude so as to produce rice be able to provide many benefits to anyone who will receive the benefits of the commodity. 2. Internalize the spiritual aspects of the agricultural activity is an effort to build a sustainable agricultural system, because every activity in managing his farm involves the spirit of continuity between all the components that are around

Recommendation: Spiritual meanings is a basic for every human being. Spirituality has far more than just make sense to be anything but more of the spiritual is able to generate support and confidence that life would be happier if internalize the spiritual in all our activities so that no imbalances in the world.

\section{References}

Dale and Daniel, J.H. (2011). Spirituality/Religion as a Healing Pathway for Survivors of Sexual Violence. In book Surviving Sexual Violence a guide to recovery and empowerment (edited by Thema BryantDa Maryland: Rowman dan Littlefield Publisher.

Hossein, S. Nasr. (1995). Man and Nature: The Spiritual Crisis of Modern Man: Indiana University. UnwinPaperbacks.

Hasan, Aliah B Purwakania (2006). Psikologi Perkembangan Islam. Jakarta: PT Raja Grafindo.

Hardin, G. 1968. The Tragedy of the Commons: Science, New Series. 162(3859). American

Association for the Advancement of Science.

Indrasari and Adnyana. (2007). Preferensi Konsumen terhadap Beras Merah. Bogor: Iptek Tanaman Pangan $2(2)$.

Nelson, J.M. (2009). Psychology, Religion and Spirituality. New York: Springer Science Business Media.

Nene, (2012). Environment and Spiritualism. Integral Parts of Ancient Indian Literature on Agriculture 1: Asian Agri-History 16(2).

Nurtjahjanti, (2010). Spiritualitas Kerja sebagai Ekspresi Keinginan Diri Karyawan untuk Mencari Makna dan Tujuan Hidup dalam Organisasi: Jurnal Psikologi Undip Vol.7,No. 1.

Suardi, K.D. (2005). Potensi Beras Merah untuk Peningkatan Mutu Pangan: Jurnal Penelitian dan Pengembangan Pertanian.

Snyder, C.R. \& Lopez, Shane J. 2007. Positive psychology: The scientific and Practical Explorations of Human Strengths. Lawrence: Sage Publications.

Zohar, D. dan I. Marshall, (2005). Spiritual Capital. Religion and Spirituality in the Quest for A Sustainable World. Bandung: PT Mizan. 